\title{
The Creation of Science Learning Models Based on Islamic Characters Deterrent Effects to Improve Student Learning Outcomes
}

\author{
Iip Aripin*, Johanes Sapri, Riyanto and Alexon \\ Doctor of Education Study Program, University of Bengkulu \\ ${ }^{*}$ Corresponding author. Email: iiparipin40@gmail.com
}

\begin{abstract}
Creation of Islamic Character-Based Science Learning Model (KMPIBKI) and the impact of accompanying models to improve student learning outcomes in Integrated Islamic Elementary Schools (SDIT) in Bengkulu City. This study aims to determine how the creation of a science learning model based on Islamic characters and its accompanying impact on improving student learning outcomes at SDIT Kota Bengkulu through the concept of dhikr and thinking (ululalbab), with a modified Research and Development (R\&D) approach through three steps: study. introduction, model development, and model validation. The research subjects were teachers and students of SDIT Kota Bengkulu. Data analysis used t-test with Statistical Package for the Social Sciences (SPSS). The results showed that: (1) based on the t-test, there is a significant difference between the Islamic character-based science learning model and the accompanying impacts including: Strengthening basic literacy character education and Higher Order Thinking Skills (HOTS), 21st century skills (Communication, Collaboration, Critical Thinking and Problem Solving, and Creativity and Innovation to improve student learning outcomes. (2) based on the independent t-test for the N-Gain score, there is a significant difference between the use of Islamic character-based science learning models and the accompanying impact compared to using conventional models on development of spiritual, social attitudes and learning achievement. (3) based on the percentage of N-Gain score, the creation of Islamic character-based science learning models is effective enough to develop the impact of accompanying models to improve student learning outcomes. KMPIBKI shows better development of spiritual attitudes, social attitudes, mastery basic literacy, HOTS, and 21st century skills. The results show that learning outcomes were significantly improved compared to the conventional learning models in SDIT Generasi Rabbani and Iqro I.
\end{abstract}

Keywords: Learning model, Islamic character, Deterrent effects, Learning outcomes.

\section{INTRODUCTION}

Education is held with the aim of educating the nation's life. The essence of education is a process to develop all of its potential to face challenges in the future. This is in accordance with the objectives of the national education system Law of the Republic of Indonesia number 20 of 2003 chapter I article 1 point 3 that education is a conscious and planned effort to create a learning atmosphere and learning process so that students actively develop their potential to have religious spiritual strength (faith), knowledgeable, competent, creative, independent, democratic, noble and responsible [1].
Based on the functions and objectives of education above, the proportion of developing student potential includes: religious spirituality, noble character, independence, democracy and responsibility, which is the development of student character as the main strength and foundation in realizing the ideals of a nation and state, namely educating the lives of all Indonesian people. built on the results of the interaction between beliefs, knowledge, experience, social environment and creative imagination about the future for every Indonesian citizen and pioneering, especially Muslims as the majority, in realizing a society with noble character is an achievement of the learning process to bring happiness to individuals, society, the nation and country. 
In this connection, Nata [2] explains that noble morals are the appearance of a person as an Islamic character to do good deeds with pleasure to achieve worldly happiness and ukhrowi. Spread kindness, provide benefit, benefit, foster love, affection as rahmatanlil'alamin [3].

Strengthening noble morals through character education based on Islamic religious beliefs, noble values, and culture through behavior management, as well as improving the quality of learning towards $21 \mathrm{st}$ century student skills, namely: critical thinking, creative, communicative, solving complex problems, collaborative, ability basic literacy such as reading and writing, arithmetic, mastery of information and communication technology, culture, citizenship and science [4]. Developing the ability to find truth, faith, piety, knowledge, noble character, character (essentialism), developing academic substance; reasoning, logic, modern language, science, mathematics (perennialism), socio-cultural vehicles in preparing students as the heirs of civilization and social change, pioneering, exemplary, collaborative, and psychopedagogical to develop student potential, centered on creative, independent, responsible students (progressivism), Winataputra [5]. The education and learning process is designed in the educational curriculum, which aims to achieve certain goals.

Achieving educational goals is faced with behavior management problems, in the form of handling antisocial behavior and decreasing learning outcomes among students. This is quite concerning because it has become a threat to the sustainability of generations, that cases of juvenile delinquency have occurred for quite a long time in various forms as released by the Indonesian Child Protection Commission, as stated in table 1 under.

Table 1. Data on juvenile delinquency cases in Indonesia

\begin{tabular}{|c|c|c|c|c|c|c|c|}
\hline Juvenile Delinquency Case & 2011 & 2012 & 2013 & 2014 & 2015 & 2016 & Total \\
\hline Children who fight student brawls & 64 & 82 & 71 & 46 & 126 & 41 & 430 \\
\hline Drug users (narcotics, cigarettes, alcohol, etc.) & 34 & 28 & 41 & 63 & 74 & 64 & 304 \\
\hline Children using drugs (narcotics, cigarettes, liquor, etc.) & 12 & 17 & 21 & 48 & 31 & 17 & 146 \\
\hline Drug trafficking children (narco-tics, cigarettes, liquor, etc.) & 48 & 66 & 63 & 67 & 93 & 93 & 430 \\
\hline Children sex offenders online & 8 & 7 & 16 & 42 & 52 & 51 & 176 \\
\hline $\begin{array}{l}\text { Children face legal violations of sexual violence (rape, forni- } \\
\text { ca-tion, sodomy/ pedophilia, etc.) }\end{array}$ & 123 & 324 & 247 & 561 & 157 & 86 & 1498 \\
\hline Children face law as perpetrators of murder & 32 & 46 & 53 & 66 & 36 & 31 & 264 \\
\hline Children facing law as perpetrators of theft & 14 & 92 & 51 & 47 & 81 & 24 & $309 ”$ \\
\hline
\end{tabular}

Another threat is the negative impact of internet use for students, the results of the study that out of 120 respondents, $54.17 \%$ of students always use the internet for online games, 50 often use the internet for online games, and only $4.1 \%$ rarely use the internet for online gaming. Where online games are clinically a psychiatric disorder or distress. The World Health Organization (WHO) in June 2018 included online game addiction in the 11 Revision International Classification of Diseases (ICD-11), calling it a gaming disorder or mental illness, Kemenkes RI [6].

There is a phenomenon above that illustrates the fragility of a sense of social solidarity among others, a lack of mutual respect, prioritizing individual interests over the interests of the crowd. There were fights between ethnic groups, races, religions, between students, community groups, etc. This shows that multiple intelligences (interpersonal and intrapersonal) are less developed from an early age and religious values (spiritual intelligence) are not used as guidelines in everyday life Safaria [7]. This is in line with Supraha [8] that education in Islam should improve one's adab (Islamic character) to others, society, the environment, the universe, the nation and the state as an implementation in carrying out God's orders hablumminallah wahablumminannas (increasing devotion and love each other human beings).

Another problem is that the science learning outcomes according to the, Ministry [9] state that the science learning process is still far from what was expected. It was released 3 December 2019 that Indonesia's ranking in 2018 decreased from 2016 from three categories assessed consecutively "category of reading ability, Indonesia is ranked 6th from the bottom, rank 74 with an average score of Indonesia is 371 , mathematics category, in 7 th place from the bottom (73) with an average score of 379 . And in the science performance category, Indonesia is in 9th place from the 
bottom (71), that is, with an average score of 379 . average score of 396 per child, OECD [10]. " This condition provides a similar indication based on the results of the average value of the National Standard School Examination (USBN) for elementary schools in Bengkulu City 2018/2019 for science subjects of 62.45 below the average value of Indonesian Language subjects (68.40) and mathematics (66.01), Hertas [11].

Based on the PISA assessment and the results of the national standard school exams above, it is hoped that they will become a capital for evaluation and motivation in assessing the quality of education at primary school age as well as being a challenge to improve various efforts to improve the quality of education including; strengthening character education, Higher Order Thinking Skills (HOTS), mastery of basic literacy, 21st century skills and the development of multiple intelligences integrated through the learning process in the classroom. The learning process is not only mastery of cognitive, affective and psychomotor aspects but is required to develop and increase student involvement in an active, creative and innovative manner under the guidance and guidance of a professional teacher and the role of teachers with Islamic character as murshid (emotionally intelligent, and provide direction towards a more fulfilling life useful), murobbi (intelligent spirituality and exemplary in increasing the meaning of life in the world and the hereafter), mualim (intellectually intelligent, inheriting knowledge and civilization), mudarrib (kinesthetic intelligence), and muaddib (morally and socially intelligent).

Another problem is that the science learning process has not been optimal, including: (1) strengthening character education (PPK) even though the 2013 curriculum implements each learning to develop basic competencies (KD) in spiritual (K1) and social (K2) aspects, but only the knowledge aspect (K3). This is due to the weak creativity and innovation of teachers to include character values in learning tools as the expected character education goals, Mulyasa [12]. Only able to develop students' scientific attitudes. Mindset of character education in religious subjects and Pancasila and Citizenship Education PPKN, Mundilarto [13]. (2) So far, learning is not meaningful and its benefits are felt for human life as a whole and human as a process of developing insight or new understanding, Sukmadinata [14]. the learning process is too theoretical and structuralist, which emphasizes the achievement of curriculum targets and cognitive values, not on problem solving, application in real life. (3) the school culture and learning have not optimized the plural intelligence which is formed from culture, the repetition of positive values. Routines form habits, which in turn form attitude. five approaches to value education (character): habituation, moral development, analysis, clarification, and the learning process". Interpersonal and intrapersonal intelligence is less developed from an early age and religious values (spiritual intelligence) are not used as guidelines in everyday life. There are a number of values that need to be taught through character education, Lickona [15].

In connection with the above, the Integrated Islamic School Network (JSIT) which houses SDIT Generasi Rabbani and Iqro 1 has an additional and strengthening curriculum of the national education curriculum (2013 curriculum) as well as a characteristic of the JSIT curriculum where Islamic values [24] (Quran and Sunnah) become the main color (sibgah) of education and the learning process

So, science learning based on Islamic characters is a learning activity that is built on intelligence (dzikir) as the main foundation, that everything related to the universe is God's creation to be grateful for being studied, explored, guarded and developed, for human welfare through meditation, tadabur activities, as intellect (thought) so as to become a perfect and perfect human (insankamilwalmutakamil) in order to have a meaningful life.

Improving the quality of learning and teacher professionalism continues to be required to be able to develop and optimize the Islamic character which is the school culture as the main basis in generating alternative learning models that are in accordance with the needs and targets of student achievement in developing multiple intelligence and learning achievement.

Starting from the description above, it is necessary to develop a science learning model based on Islamic characters and the impact of the accompanying model in improving learning outcomes in integrated Islamic elementary schools in Bengkulu City.

Research objectives was to describe the development of a science learning model based on Islamic characters, the impact of accompanying the model and its effectiveness for student learning outcomes in SDIT Kota Bengkulu.

\section{LITERATURE REVIEW}

Effectiveness of online quality assurance management model with knowledge management system principal approach. The effectiveness of a learning program with regard to the problem of achieving learning objectives and the level of satisfaction of the individuals involved in learning. Learning is said to be effective if in the learning process each element functions as a whole, participants feel happy, satisfied with the learning results, make an impression, adequate facilities / facilities, affordable materials and methods, professional teachers. The main review of the effectiveness of learning is its output, namely the competence of learners. Effectiveness can be achieved if all the elements and components contained in the learning system function in accordance with the 
goals and objectives set. The effectiveness of learning can be achieved if the design in preparation, implementation, and evaluation can be carried out according to procedures and in accordance with their respective functions.

Learning is a set of systematic processes in organizing learning events and experiences through educational interaction activities between students and learning resources to achieve learning goals. The learning model is a conceptual framework that describes a systematic procedure for organizing learning experiences to achieve specific learning objectives and serves as a guide for teacher learning planning in designing and implementing the teaching and learning process, Bruce [16].

The Islamic character-based science learning model (MPIBKI) is one of the learning development models built on a theoretical basis, including: (1) repetition, which is the most intuitive learning principle that is obtained from the Kauliyah verses starting from the process of human creation. first (Adam as.) who was taught a variety of names (objects) entirely, then conveyed to the Angels and then spoke; Call ME the names of the things if you are true people, At-tabari [17]. This is in line with Ronis [18] that the learning process that is repeated at least fifteen times a day or done ten times will form skills, habits and character. (2) Gestalt holistic theory that the development of new understandings is a form of developing a whole individual, a pattern of unity and a whole that involves all aspects of a child's life.

With regard to this Gestalt concept, Sukmadinata [19] suggests that learning is a process of developing new insights or understanding. Understanding occurs when individuals find new ways to use the elements in the environment. " In application, Gestalt theory emphasizes the acquisition of insights where students have the ability to recognize the relationship of elements in an object or event. (3) Thorndike's theory the more often a behavior is repeated / trained (used), the stronger the association will be. (4) Pavlov classical conditioning theory (classical conditioning), namely the mechanism for presenting new responses. In connection with that Eagly [20] states that the theory of planned behavior which is built on good understanding, guidance, mentoring, consideration for the life to come, logically moves motivation and strength to behave consistently (5) theory Edgar Dale stated that learning can be optimally mastered, understood and absorbed by students when there is active involvement of students in the form of involvement, experiencing, feeling as conveyed in the edgar dale theory with cone of experience, Steven [21].

An integrated Islamic school is a school that has characteristics, where Islamic values are the main color (sibgoh) in shaping a school culture that is integrated with the education and learning process to become a generation of ahlul dzikir and thingking (ulul albab).

Conceptually the MPIBKI learning concept emphasizes dzikir and thingking (ulul albab) where the material to be delivered is not in the final form but students are encouraged to identify what they want to know by organizing, constructing, and classifying them in groups and independently to be applied in a built world for his belief (ukhrowi) as worship ghoiru mahdoh, Supraha [22].

Learning activities, believing that knowledge comes from the Creator (God), gathering information (kauliyah and kauniyah) through the "Integrated" process, namely: Study (comparing), Exploration (developing, categorizing, analyzing,) Formulating (conception), Presentation (testing, comparing, maintaining), applying (integrating, concluding) the worldly (reflection, benefit, and application in everyday life) and ukhrowi (belief, meaningfulness to practice as worship).

Students are said to understand a MPIBKI concept seen from the following aspects: (1) the dzikir aspect, that the source of barasal knowledge from God Almighty is in the form of kauliyah verses (Qur'an and Sunnah) as a belief, (2) aspects of thinking that science originating from all of God's Almighty creations in the form of kauniyah verses (universe / cosmos) which require to be discovered, developed, practiced, and applied as a habit (habituation) for human happiness and well-being. The dzikir and fikri aspects are one unit (holistic / integrated) in the education and learning process. Students are said to have mastered the concept of science from the dzikir aspect when mastering the three elements of dhikr including: (a) science is one unit (dzikir and fikir), (b) applies it in life as worship. (c) deepen, develop, discover, and make it happen, requiring sacrifice as charity jihad. Whereas from the aspect of thinking, mastering the five elements of the thought aspect, including: (a) the name of the object being studied, (b) understanding its examples, both positive and negative, (c) knowing the characteristics, both basic and not, (d) range characteristics and (e) the rules (rules).

The syntax for developing MPIBKI in increasing multiple intelligence and learning achievement can be seen in Table 2. 
Table 2. Syntax of integrated Islamic school learning model

\begin{tabular}{|c|c|c|}
\hline Phase & $\begin{array}{c}\text { MPIBKI } \\
\text { (UlulAlbab) }\end{array}$ & The Teacher's Role \\
\hline $\begin{array}{l}\text { Introduction } \\
\text { Orchestration }\end{array}$ & $\begin{array}{l}\text { Orchestration } \\
\text { Instructional }\end{array}$ & $\begin{array}{l}\text { The teacher explains the goals, competencies to be achieved and motivates } \\
\text { to be involved in all learning activities and problem solving as part of } \\
\text { charity. }\end{array}$ \\
\hline 1. Review & $\begin{array}{l}\text { Scientific } \\
\text { Attitude }\end{array}$ & $\begin{array}{l}\text { The teacher guides the preparation of students to have initial skills in } \\
\text { learning through various activities to examine the basic concepts of the } \\
\text { material by seeing, listening, reading, listening, studying, observing, } \\
\text { analyzing related to stories, pictures and events. }\end{array}$ \\
\hline 2. Exploration & \multirow{3}{*}{$\begin{array}{l}\text { High } \\
\text { Order } \\
\text { Thinking } \\
\text { Skilland } \\
\text { Basic } \\
\text { Literation }\end{array}$} & $\begin{array}{l}\text { 2. The teacher guides the process of extracting, investigating knowledge, } \\
\text { and finding concepts through collecting, organizing and interpreting } \\
\text { information, data, to get explanations and problem solving, lessons, } \\
\text { lessons learned through various methods and learning strategies. }\end{array}$ \\
\hline 3. Formulate & & $\begin{array}{l}\text { The teacher guides the formulation of exploration results through various } \\
\text { discussion activities, data analysis, facts or steps to draw conclusions. }\end{array}$ \\
\hline 4. Presentation & & $\begin{array}{l}\text { The teacher communicates the findings, formulations, concepts and } \\
\text { solutions through various forms of presentation, presents various } \\
\text { information then communicates the results of the conceptions in oral, } \\
\text { written, pictures or other media. }\end{array}$ \\
\hline 5.Application & \multirow[t]{3}{*}{$\begin{array}{l}\text { Spiritual } \\
\text { Attitude }\end{array}$} & $\begin{array}{l}\text { The teacher guides, creates a learning climate, and reflects on the learning } \\
\text { process to be able to apply conceptual understanding, both through } \\
\text { activities, emergence and problem solving related to issues in the } \\
\text { environment and in his life, and the application of learning outcomes } \\
\text { through guided activities. }\end{array}$ \\
\hline 6. Worldly & & $\begin{array}{l}\text { The teacher emphasizes and motivates students about the relationship } \\
\text { between knowledge gained and daily activities to be used as good habits, } \\
\text { which are continuously carried out, practiced until they become } \\
\text { habituated. }\end{array}$ \\
\hline 7.Ukhrow & & $\begin{array}{l}\text { The teacher emphasizes and motivates students about the relationship } \\
\text { between the knowledge gained and daily activities that can become } \\
\text { righteous deeds in accordance with Allah's commands. }\end{array}$ \\
\hline
\end{tabular}

The teacher guides, directs students that all human life ends in reward and sin, success and failure, happiness and misery. God's grace and punishment as well as internalizing it by finding, finding and memorizing verses and hadiths as a frame for all actions that are carried out. The teacher guides, directs and accompanies students: showing attitude,

8.Communication

SKILLS21st

Century cheerfulness, smiling, greeting, praying, helping, listening, talking, polite, polite and respectful.

9. Collaboration

The teacher guides, directs students: Cooperation, interaction, compromise, listening, speaking, courtesy and respect.

\section{Integration of MPIBKI, PPK, Literacy, HOTS and 21st Century Skills}

The various views above are in principle development (MPIBKI) is the development of learning that integrates various approaches to the learning process and anticipates challenges in the future, through seven stages of developing core learning, namely; study, explore, formulate, present, to be applied by the world and ukhrowi
The Islamic character learning model as a learning paradigm by integrating $21 \mathrm{st}$ century skills (4C) strengthening character education (PPK), mastery of literacy and HOTS to provide learning that: (1) provides learning experiences to students, (2) encourages a school ecosystem based on scientific activities and the application of belief (faith) as a school culture, (3) challenging to solve problems, (4) motivating, (5) activity and creativity based, (6) inspiring, (7) fun, (8) initiative and (9) meaningful designed through a Learning Implementation Plan (RPP), as a learning platform for the future (21st century). 


\section{RESEARCH METHODS}

The research procedure carried out in the development of Islamic character-based science learning models on plural intelligence and learning achievement is a modified combination of the models, Borg [23] and Sukmadinata [24], with three stages, namely (1) study preliminary, including: literature study, field survey, analysis and interpretation, (2) model development includes: initial draft model, four round limited trial, four rounds wide trial, and hypothetical model, and (3) model validation includes: pretest tested models and treatments. The research subjects were teachers and fifth grade students at SDIT Generasi Rabbani and Iqro I Bengkulu City. Data analysis used t-test and N-Gain score with the researchsteps developed as shown in figure 1 below.

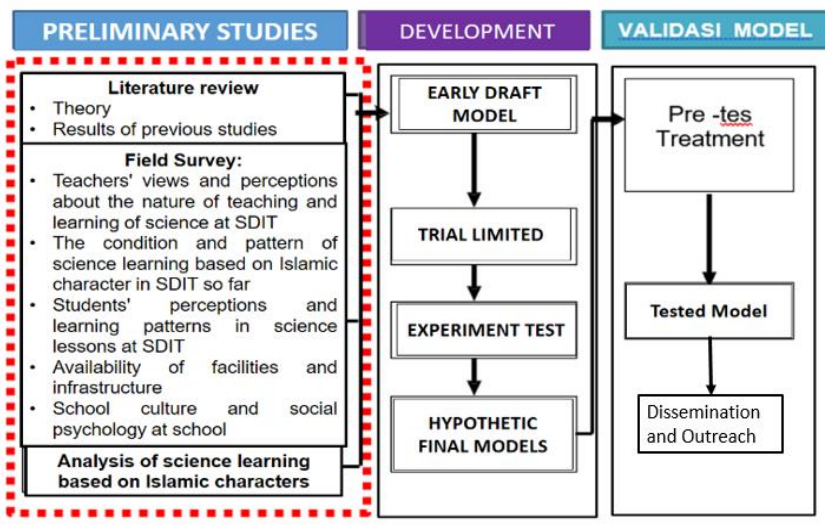

Figure 1. Modification of research and development procedures

The research was conducted at SDIT Generasi Rabbani and SDIT Iqro I Bengkulu City. The time of research was carried out from July 2019 to January 2020.

The research subjects of class V students and parents in the 2019/2020 school year at SDIT Generasi Rabbani and Iqro I which were used as research subjects were carried out based on purposive sampling, namely the determination of research subjects based on certain considerations, Sugiono[25], in the form of emotional maturity, and not being busy. with lesson assignments in facing the national exam if done in class VI. The total number of students in grade V from 2 SDIT was 202 students, and subjects who met the requirements in data processing for research purposes were 86 students, with the instruments used, the questionnaire instruments, the observation instruments, documents, and the test instruments.

\section{RESULTS AND DISCUSSION}

\subsection{Results}

The results of the pre-survey showed that most teachers $(81.3 \%)$ thought that science learning at SDIT was a rote lesson, which required analysis, logic, systematic and life-related and could be integrated with character content. While conceptually the science subject matter, especially class V SDIT, is related to everyday life, it can be integrated with character learning $(83.4 \%)$, although there are still some who admit $(10.13 \%)$ that the demands of the science subject curriculum There are so many things that must be completed, so there is no need to be associated with anything else that is not relevant, including character, the learning process is quite focused on conveying as much knowledge as possible and mastering science material.

The Learning Implementation Plan (RPP) of all teachers $(100 \%)$ has made learning tools, but the Learning Implementation Plan (RPP) used in the classroom $(71.9 \%)$ comes from textbooks, downloaded from the internet, from other schools or lesson plans before. They did this because they felt they no longer needed to study the curriculum in depth. The study of the curriculum, which should have preceded the process of preparing the lesson plans, was not carried out because the science textbooks used were considered representative. In addition, there is an opinion from most of them $(84.4 \%)$ that teaching is a routine job that is usually done so that it does not require special preparation and teachers feel that they have memorized what to do, some even think that lesson plans $(43,75 \%)$ is only in the form of administrative purposes, that is, it is only used if there is an inspection, supervision or for accreditation purposes. Meanwhile, student and teacher learning resources already have handbooks (100\%), becoming the main learning source through procurement in collaboration with the private sector. The way students learn in class, according to most students $(61.6 \%)$, is to explain more of the learning material in the book, the learning is occasionally continued to discuss and do the exercises in the textbook, while the opinions of students on the purpose of learning science $(64 \%)$ in order to get good grades and move up the grade, while studying science in order to obtain science knowledge that is useful for life $(30.2 \%)$. "

"Based on theoretical studies, the results of the presurvey, and the results of discussions with the teachers who were the research subjects, the initial design (draft) of the model was developed, then it was carried out with limited model trials carried out in four rounds, aiming to develop an initial draft model that had designed. through the development of learning activities after the core being developed includes: study (compare), explore (develop, categorize, analyze,) formulate (conception), present (test, compare, defend), apply (integrate, conclude,) mundane (reflection, and application in everyday life) and ukhrowi (belief, meaningfulness to practice as worship). After a limited trial, a wider trial was then carried out to find the MPIBKI as a standard learning model and can be implemented in the rabbani 
and Iqro I generation schools, carried out in four rounds. This is based on the belief that MPTBB, both based on observations and quantitative statistical calculations, has been developed and is deemed adequate in accordance with the stated objectives. After the model is found, the validation process is carried out

As a unity, they become ahluldzikir and thinkers that are manifested in everyday life so that they have benefits for a wider life. All learning activity processes (preliminary, core and closing) are fun orchestration for all and experimental tests are carried out to improve multiple intelligence and learning achievement and the accompanying impact.

The results of the validity test prove that the use of MPIBKI in science subjects in SDIT not only improves plural intelligence and learning achievement but has the accompanying impact needed in welcoming the Indonesian golden generation in 2045 .

The learning process using the MPIBKI model in each school in terms of student involvement and activeness and the impact of accompaniment can be seen in figure 2 below.

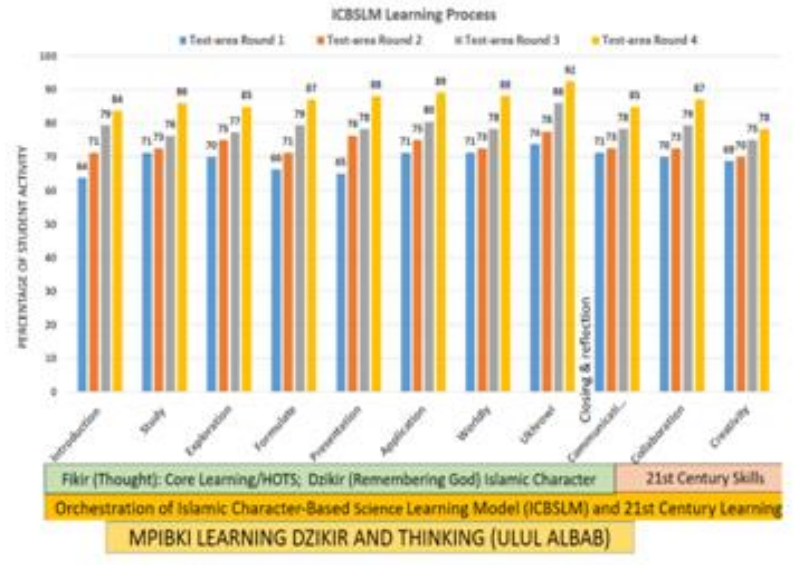

Figure 2. Comparison of the average acquisition of the MPIBKI learning process in the area-test

Based on the results of observations of the application of the MPIBKI, for the broad-test in Figure 4. provides an illustration that there is an increase in each cycle that tends to increase, from building an atmosphere of togetherness, joy and togetherness and student activity during the learning process as well as the impact of accompanying models including strengthening character education, spiritual attitudes, social, basic literacy and 21st century communication skills, collaborative, creative and innovative.

Table 3. MPIBKI, deterrent efffects model and learning outcomes in SDIT Generation Rabbani and Iqro 1 Schools in Bengkulu City

\begin{tabular}{|c|c|c|c|c|c|c|c|c|}
\hline \multirow[b]{2}{*}{$\begin{array}{l}\text { Research } \\
\text { Objects }\end{array}$} & \multirow[b]{2}{*}{$\begin{array}{l}\text { D } \\
8 \\
\frac{0}{0} \\
\text { in }\end{array}$} & \multirow[b]{2}{*}{$\mathrm{N}$} & \multirow[b]{2}{*}{ Group } & \multicolumn{3}{|l|}{ Average } & Test result & \multirow[b]{2}{*}{ Description } \\
\hline & & & & EXP & CTR & $\stackrel{\Xi}{E}$ & $\begin{array}{c}\text { Ttab (two tail) } \\
+0.05\end{array}$ & \\
\hline \multirow{10}{*}{$\begin{array}{c}\text { Deterrent } \\
\text { Effects } \\
\text { Model }\end{array}$} & \multirow{10}{*}{ 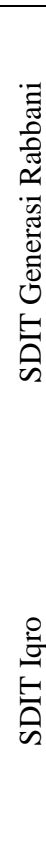 } & & Social & 36.96 & 31.45 & -2.8 & 2.09 & Significant \\
\hline & & & Spirituality & 38.6 & 31.5 & -3.5 & 2.09 & Significant \\
\hline & & 0 & $\begin{array}{l}\text { Literacy and } \\
\text { HOTS }\end{array}$ & 36.10 & 31,25 & -2.9 & 2.09 & Significant \\
\hline & & 20 & $\begin{array}{l}\text { Islamic } \\
\text { character }\end{array}$ & 37.6 & 31.63 & -3.5 & 2.09 & Significant \\
\hline & & & $\begin{array}{l}21 \text { st century } \\
\text { skills }\end{array}$ & 36.3 & 31.4 & -2.6 & 2.09 & Significant \\
\hline & & & Social & 34.7 & 29.7 & -3.5 & 2.07 & Significant \\
\hline & & \multirow{4}{*}{23} & Spirituality & 38.8 & 33.57 & -3.5 & 2.07 & Significant \\
\hline & & & $\begin{array}{l}\text { Literacy and } \\
\text { HOTS }\end{array}$ & 35.8 & 29.7 & -3.4 & 2.07 & Significant \\
\hline & & & $\begin{array}{l}\text { Islamic } \\
\text { character }\end{array}$ & 37.5 & 33.57 & -3.7 & 2.07 & Significant \\
\hline & & & $\begin{array}{l}\text { 21st century } \\
\text { skills }\end{array}$ & 38.1 & 33.57 & -3.3 & 2.07 & Significant \\
\hline
\end{tabular}




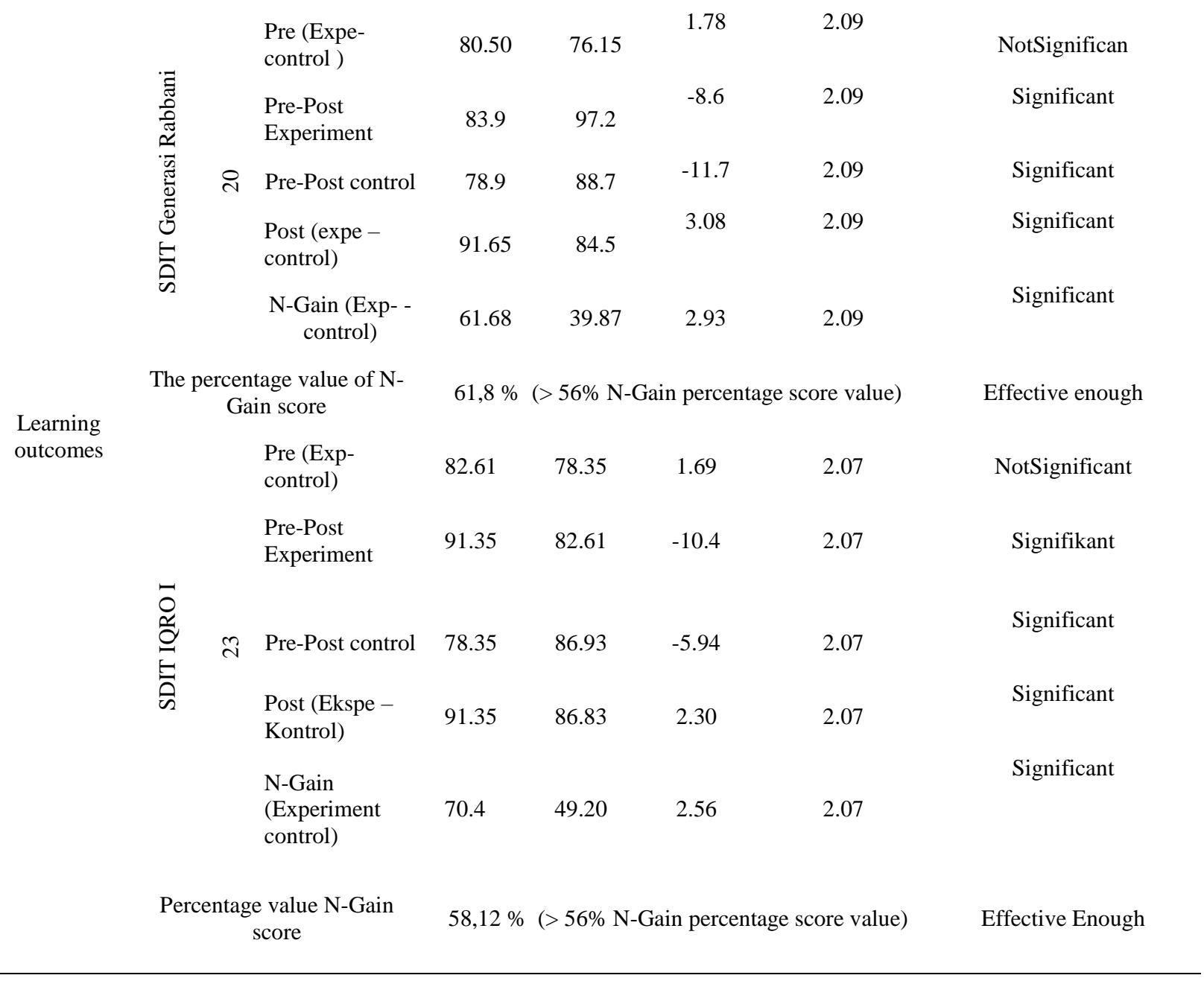

In the validity test of the experiment and control on the impact of accompaniment including spiritual attitudes, social, basic literacy mastery, HOTS, strengthening character education, 21st century skills show significant results, but in the early stages learning outcomes do not show significant differences in the experimental group and the group control but in the final test showed a significant difference, likewise the $\mathrm{N}$-Gain score of the experimental group and the control group showed a significant effect. Being seen from the percentage value of the $\mathrm{N}$-Gain score of $58.12 \%$ and $61.2 \%$, which is greater than the N-Gain score of $56.0 \%$, MPIBKI is quite effective in being applied in characterbased science learning to improve plural intelligence and learning achievement.

\section{2 Discussion}

In value, the MPIBKI concept is to improve multiple intelligence and learning achievement, with the concept of dzikir and thinking (ululalbab) approach which is integrated in the science learning process, becomes an alternative learning model to improve multiple intelligence and learning achievement and has an accompanying impact in developing character by building Strengths: (1) transcendental vertical relationships as a strengthening of spiritual intelligence (mahdoh worship), (2) increasing horizontal interpersonal social relationships (worship ghoirumahdoh), and (3) increasing self-integrity (interpersonal). Everything is done in sharpening the sensitivity to provide a variety of meanings and benefits, has relevance to the limitations of the human thought process because it has not been able to open the veil and understand because of limited thinking (functional), everything is returned to the belief that God created something has a purpose (nothing is in vain).

Everything is built on the learning process to produce students who have a vision based on the values of eternal truth (perennial) and slander constructed from the experiences they have gone through, to obtain new values, wisdom, meaningful life. Not only from the aspect of thought (insight) as with regard to the Gestalt concept which states that "learning is a process of developing new insights or understanding that occurs when individuals find new ways to use the elements that are around them". This requires a refinement of the theory that the insights conveyed by Gestalt need to be strengthened by overall involvement to produce new understandings for students that come from dhikr (intelligence of the heart). 
So, regarding the view of a holistic approach that prioritizes learning that is whole, whole and concrete, so that students learn meaningful, authentic and active, everything should be viewed as a whole, not only from the aspects of the learning process and material (secularistic) which originates from the thinking process, but needs to be refined. with the whole of the dhikr aspic (intelligence of the heart) which will guide the perfection of knowledge, thoughts, works, initiative, creativity and meaningful life in realizing human welfare and happiness in the worldly and ukhrowinya.

Learning at SDIT emphasizes the foundation of goodness in carrying out the kauliyah verse (hadith) that in humans there is a lump of flesh, if it is good, it is good for humans, but if it is damaged, it is corrupted and there is a heart (fu'ad). In this regard, Tasmaran [27] states that the heart (fu'ad) provides space for meditation, choosing and choosing, as well as remembrance as a space and place for humans to remember and dzikir to God. This is the meaning of the integrity of science as conveyed by Sarton [28] which explains that "science and religion (belief) cannot be separated, and one cannot understand one without understanding the other". This is in line with Draver [29] that "the harmonization of science and religion is so good in the country of Islam that science is very developed along with the higher religious zeal".

The process of involvement in all learning processes by actively involving students in the classroom, supported by an Islamic school culture along with the involvement of parents at home by providing assistance both in the use of information and communication technology, exemplary, openness, togetherness and full of love. played by parents at home and returning to school get the same assistance, continue to be carried out repeatedly as a process of habituation (habituation) will accelerate the growth of character values such as caring, responsibility, honesty, courage to convey thoughts and opinions, defend in his opinion, as a concept testing event in the discussion process, being involved in solving problems together is a concrete experience felt by children. This condition not only builds a child's memory system in the long term (long term memory) as in the theory view with the cone of experience that $80 \%$ of learning is achieved because of student involvement but it fosters the learning process. Bringing the abstract world to the concrete world as Piaget's view that the cognitive development of elementary school aged children is still a concrete operation where the child cannot understand abstract problems, so presenting it to the concrete world (real) in the learning process is the right approach.

\section{CONCLUSIONS AND SUGGESTION}

MPIBKI framed that the learning process is a fun orchestration, building togetherness begins with singing compulsory songs, with nasyid (reading badar prayers), there are stories, stories and others which are an effort to bring love to the main characters, namely the Prophet. As an ideal human figure who needs to be recognized and imitated in all student behavior, other students generate love by presenting independence heroes who have liberated the Indonesian nation from colonialism, their enthusiasm and nationalism need to be stimulated, grateful and need to be continued by building an understanding that learning, exploring knowledge, including science, is the value of nationalism and love for the country in the form of protecting and maintaining the environment, maintaining and maintaining a healthy lifestyle, equipping oneself with knowledge, skills and fostering good character to build Indonesian civilization to provide meaningful benefits in life. life) for the others.

The discussion above shows that the MPIBKI is a learning model developed differently from other learning models. The purpose of the MPIBKI is not only an effort to improve multiple intelligence and learning achievement in the form of mastery of science material, but to prepare students to build and develop basic literacy mastery, strengthening character education, high-level learning (HOTS) and 21st century skills as an impact of accompanying the model, towards 21st century learning as an effort towards a golden Indonesia in 2045 .

First, Islamic Character-based Science Learning Creation (MPIBKI) (1) Can increase the accompanying impact of the creation of learning models in the form of strengthening character education, mastery of basic literacy, High Order Thinking Skills (HOTS) and 21st century skills (collaborative, creative, critical thinking, communicative ), and the results of learning science at SDIT Generasi Rabbani and Iqro 1, (2) Implementation of learning activities includes seven stages of learning with a dzikir and thought frame, namely: introduction, analysis, exploration, formulation, presentation, application, worldly and ukhrawi and closing becomes integrated learning process between heart and mind.

Second, the Islamic Character-Based Science Learning Model (MPIBKI) is proven to be significantly more effective in improving learning outcomes due to the impact of the sender when compared to the learning model that has been practiced by teachers so far.

The conclusions above have various implications, namely (1) changing the role of the teacher in the learning process from presenters to mentors, assistants and Uswah (good examples of spiritual and social attitudes (2) teachers need creativity and initial provision, (3) optimal learning facilities and infrastructure, (4) strengthening the vision of togetherness between schools and parents regarding education for their children. 


\section{REFERENCES}

[1] Law of the National Education System of the Republic of Indonesia Number 20 of 2003 Chapter I article 1 number 3.

[2] Nata Abuddin. Akhlak Tasawuf. Jakarta: PT Raja Grafindo Persada. 2009.

[3] Ash-shafi, F. Masytu 'Al-Ishlah Al-'Aalami. (Translation by Auliya, Khozin. Jakarta: Al I.tishom, 2018.

[4] Ministry, Education and Culture of the Republic of Indonesia. The Release Program of Achievement Value for International Student Assessment (PISA), Jakarta, 2016.

[5] Winataputra, Udin S. Model-model pembelajaran Inovatif. Universitas Terbuka, Jakarta. 2001.

[6] Kemenkes RI. Kecanduan Game Adalah Gangguan Perilaku. 2018

[7] Safaria T. Interpersonal Intelligence Metode Pengembangan Kecerdasan Interpersonal Anak. Yogyakarta, 2008

[8] Supraha, W. George Sarton's Thought \& Guide to the Islamization of Science. Adab Insan Mulia Foundation, 2018.

[9] Ministry, Education and Culture of the Republic of Indonesia. The Release Program of Achievement Value for International Student Assessment (PISA), Jakarta, 2016.

[10] OECD. PISA Result in Focus, 2018a. https:// www.oecd.org/pisa/2015-results-in- focus.pdf.

[11] Hertas. Results of Unas SD in Bengkulu City, SDN 8 rule the highest level of Unas City in Bengkulu Radar City, 2019. https://www.radarbengkulu line.com (downloaded 12 February 2020)

[12] Mulyasa, E,Menjadi Guru Profesional (Bandung : Remaja Rosda karya, 2003)

[13] Mundilarto. Konsep dan Strategi Pendidikan Kewarganegaraan di Sekolah: Tinjauan PsikoPedagogis (Paper). Pamulang. 2013.

[14] Sukmadinata, N.S. Educational Research Methods. Bandung: PT Remaja Rosda karya, 2008.

[15] Lickona, Thomas. Education for Character: Mendidik untuk Membentuk Karakter. Jakarta: PT Bumi Aksara. 2012.
[16] Bruce, Weil, M., Calhoun. Model of Teaching. (translators Fawaid and mirza) Eighth edition. Student Library Publisher, 2011.

[17] At-Ṭabarī, I. J. Date of al-Rasul wal al- Muluk volume 1, translated into English by Franz Rosenthal. State University of New York Press: New York, 1989, pp. 265-268.

[18] Ronis, D. L., Yates, J. F., \&Kirscht, J. P. Attitudes, decisions, and habits as determinants of repeated behavior. In A. R. Pratkanis, S. J. Breckler, \& A. G. Greenwald (Eds.), Attitude structure and function (pp. 213-239). Hillsdale, NJ: Lawrence Erlbaum, 1989.

[19] Sukmadinata, N.S. Educational Research Methods. Bandung: PT Remaja Rosda karya, 2008.

[20] Eagly, A. H. \&Chaiken, S. The Psychology of Attitudes. Fort Worth, TX: Harcourt Brace Jovanovich, 1993.

[21] Steven, H. The Educational Technology Handbook a Comprehensive Guide: Process and Product for Learning. Englewood Cliffs: Educational Technology Publications, 1996.

[22] Supraha, W. George Sarton's Thought \& Guide to the Islamization of Science. Adab Insan Mulia Foundation, 2018.

[23] Borg, W, R, Gall, J.P. and Gall, M.D. Education research: An Introduction: Seventh Edition, Boston New York, 2003.

[24] Sukmadinata, N.S. Educational Research Methods. Bandung: PT Remaja Rosda karya, 2008.

[25] Sugiyono. Metode Penelitian Kuantitatif, Kualitatif, $R \& D$. Bandung: CV Alfabeta, 2019.

[26] Sukmadinata,N. S. Landasan Psikologi Proses Pendidikan,Bandung: PT RosdaKarya, 2005.

[27] Tasmara, T.Cultivating Islamic work ethic, Jakarta: Echo Insani, 2004.

[28] Sarton, G. Introduction to the History of Science, Florida: Carnegie Institution of Washington, 1927.

[29] Draper, J.W.History of the Conflict Between Religion and Science, New York: D. Appleton and Company, 1882. 